\title{
The Analysis of Curriculum Reform in Public Computer Course in Universities based on Foster Ability
}

\author{
Hua Xiang, Bin Yan \\ School of Mathematics and Computer Science, Jianghan University, Wuhan, China \\ xhry@sohu.com, bin_yan_1@163.com
}

\begin{abstract}
By analyzinge the problems in public computer course in universities, it is aim to increase the students' comprehensive abilitiey, innovation ability and autonomous learning ability. It is proposed that the public computer course is divided into six modules, different computer courses is set in each modules. Two measures is proposed in the reform, one is the teaching model which based on "classroom teaching+class exercise+self-directed exercise", the other is the evaluation system of learning effects which targete the competence assessment.

Index Terms - public computer courses, curriculum system, teaching model, evaluation system
\end{abstract}

\section{I . Current problems in public computer course in universities}

Public computer course is an indispensable part of university teaching. Computer is the basic skills of university students. Computer courses have the practical and applied properties. The primary mission of computer courses is retain computer knowledge and develop computer application ability of students. Students may use computer as a base tool in their work and study after learning public computer courses.

The curriculum system of public computer course is divided into two parts: basic computer courses and programming language courses. University Computer Basis is the first computer course for freshmen. It covers the basic concepts of computer, general software such as Windows, MS Office, basic knowledge of network. Programming language courses are divided into Visual $\mathrm{C}++$ programming, Visual Basic programming, Java programming, Visual FoxPro programming, Access programming. The courses were organized by department of Students.

A lot of problem are found to exist in curriculum system of public computer course by Years of teaching practice:

\section{A . The level of students is quite different in classroom, whose receptivity is quite different.}

The public computer course is compulsory course for every university students where they received different information technology education. Computer knowledge of freshmen is quite different because they are from different regions. Some students from developed regions are comparatively basic operating skills of computer. They are reluctant to repetitive learning what they have already known. While some students from remote regions never used a computer, they have to learn every thing about the computer, even boot and shutdown.

Students who have different interests and logical skills perform differently in learning the course. For example, science and engineering students have a good ability of logical thinking and judgement. They can understand the content of program design courses easily. But most liberal arts students have lots of problems in program design courses. They have to spend more time on studying.

$B$. Content of the courses is disconnected from the demands of students, and gaps exist in the content of courses and societal needs.

University Computer Basis only teach students basic operation of computer such as Windows, MS Office, Internet, but it doesn't teach senior computer operation. Students are unable to edit long documents in word and analysis experimental data in excel after study university computer basis. Most students only grasp the basic programming method after programming courses, but they couldn't write code for their majors.

Employers demand students who have excellent computer skills and can grasp a new software quickly in their work. But the operation of some common softwares such as multimedia software, utility software, security software aren't taught in computer courses. Content of courses still fell considerably short of employ claim to students' computer ability. Refernce [1] suggested that practical teaching must be highly valued in curriculum system to improve the students' ability to slove practical problems.

C. The traditional computer teaching methods care about passing on the knowledge but neglect the cultivation of undergraduates' information literacy.

Teachers pay attention to cultivate application ability of students in their courses, but neglect to cultivate the ability to use knowledge to solve practical problems. It is particularly true in computer teaching processes. Students master copy files, edit document, .create sheets during courses, but they couldn't complete complex operations by themselves.

It is common that students don't know what to do and where to start because of lacking autonomous learning learning ability which is often ignored in public computer courses.

\footnotetext{
* This work is partially supported by Hubei Province Educational Science Twelfth Five-Year Planning Project (No. 2011B414) and Teaching Research Project from Hubei Education Department (No. 2011251) .
} 


\section{II . The project of new curriculum reform}

To solve these problems, the need for Computer curriculum system reform is urgent. In order to improve students' comprehensive ability and innovation, the new curriculum system is divided into six course modules on the basis of students' level, ability and requirement.

\section{A. Reform of curricular system}

Public computer course is composed of six course modules which includes Introduction to computer, Computer applications, Advanced programming language, Database application, Network technology, Multimedia technology. As shown in table I, each module consists of several courses.

University Computer Basis is the first compulsory course for freshmen, including fundamentals of software and hardware, basic operation of Windows, base knowledge of network. Four periods are scheduled at the end of the term introducing students to the content and learning method of subsequent courses, thus guiding them to take courses.

TABLE I Computer curriculum system

\begin{tabular}{|l|l|}
\hline Course module & Courses \\
\hline Introduction to computer & University Computer Basis \\
\hline Computer applications & $\begin{array}{l}\text { Basic Applications of Office } \\
\text { Advanced Applicatons of Office } \\
\text { Basic Tools and Software }\end{array}$ \\
\hline $\begin{array}{l}\text { Advanced programming } \\
\text { language }\end{array}$ & $\begin{array}{l}\text { C Language Programing } \\
\text { Visual Basic Programming } \\
\text { Java Programming }\end{array}$ \\
\hline Database application & Visual FoxPro, Access, MySQL \\
\hline \multirow{3}{*}{ Network technology } & $\begin{array}{l}\text { Common network Software } \\
\text { Web Design and Production } \\
\text { Internet Applications }\end{array}$ \\
\hline \multirow{3}{*}{ Multimedia technology } & $\begin{array}{l}\text { Photoshop } \\
\text { Flash } \\
\text { 3DS MAX } \\
\text { Audio Acquisition and Processing } \\
\\
\text { Video Processing } \\
\text { Multimedia Integration Technology }\end{array}$ \\
\hline
\end{tabular}

Computer applications module consists of Basic Applications of Office, Advanced Applications of Office, Basic Tools and Software. Basic Applications of Office is Compulsory Course. The content is based on grade $1 \mathrm{MS}$ office of NCRE. Advanced Applications of Office and Basic Tools and Software are optional courses. The content of Advanced Applications of Office is based on grade 2 MS office of NCRE. Student will be familiar with general operations of Computer and common software after studying these courses.

Advanced Programming Language module is compulsory course for students of science and engineering. The course is based on corresponding language of grade 2 of NCRE. Students are supposed to be equipped with the ability to design programs by using advanced computer language after learning..

Database application module are compulsory course for students of business and liberal arts. By learning these courses, students could use DBMS to process information in their study and work and be able to pass the exam of NERE.

The courses in network technology module teach students operation of network, web design and internet technology. The content of Multimedia technology module is on operation of multimedia software such as Photoshop, Flash, 3DS Max, Audition, Premiere. These courses are interdisciplinary elective courses. Students can take these courses in accordance with their professional needs and interests.

An examination is organized before course taking in Basic Applications of Office, Advanced Applications of Office and programming courses. Exam content and difficulty are the same as the final exam. Students whose scores are over 85 have mastered the course content. These students are allowed to exempt from these courses. The same goes for the students who pass corresponding level in NCRE.

\section{B. Teaching Mode Innovation}

Traditional teaching focuses only on passing on the knowledge rather than the development of the students' ability. The experiments of computer courses are not exception. Verification experiments can't meet the demands of students'. They are supposed to be designed to solve practical issues and improve ability to analyzing and solve problems.

Reference [2] illustrated that American psychologist Howard Gardner has proposed the theory that human's intelligence is multiple, and their Individual needs is diverse. Based on this theory, multi-pattern teaching modes are supposed to be applied during the teaching attaching importance to individual needs.

In this sense, the core of teaching the public computer course is changing from teaching by teacher to learning by students. Reference [3] proposed that traditional teaching mode which is teaching in multimedia classroom and experimentalize in computer room changed to new teaching mode which is teaching verification in computer and autonomous learning. The focus of teaching has shifted to how to cultivate students' information literacy and autonomous learning ability. Students are supposed to use the computer to help with their work after learning courses.

National laboratories in US had made a investigation on learning retention rate in various ways this decade. The results show that learning retention rate of learning in traditional teaching method is only $5 \%$ left, but learning retention rate of discussion, demonstration and teaching others is up to $60 \%$. Aiming at strong practicality of public computer courses, we conduct concurrent interactive teaching under network multimedia teaching system. Teachers illustrate the content in broadcast window. Students follow the operation in operating window. Because of the synchronous teaching processes and verification experiment, students will have master the knowledge in a intuitive way and left a deeply impression of the learning content. In the process of teaching, efficiency will be available by questioning discussing and interacting. Students' enthusiasm and initiative can be also aroused and a learning atmosphere is created in this way. 
Autonomous learning rooms and network platform are set up to construct provide students with an appropriate environment for independent study. Thirty independent hours are assigned to students every term. Students could ask for more free hours when they need. Autonomous learning rooms are open every afternoon and evening. Students could do comprehensive experiment and study under teachers' guidance. Students could download curriculum resource, submit comprehensive experiment, view evaluation from teacher, do independent test and discuss problems on autonomous learning platform. On platform, teacher could assign comprehensive experiment and guide students to complete it. It's helpful to cultivate students' information literacy and independent learning ability.

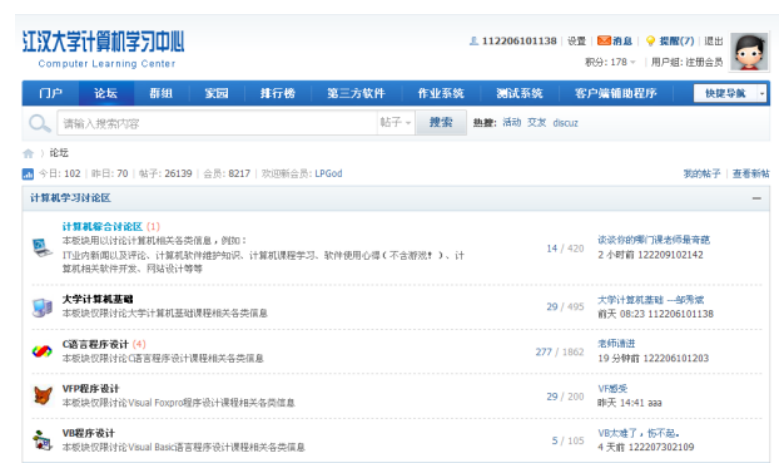

Fig. 1 Autonomous learning platform

\section{The reform of learning effect evaluation system}

Computer-based exam are used in most public computer courses to evaluate the effect of study. It's a way of evaluating proficiency in the knowledge students have acquired. Students could achieve good grades by reviewing contents before exams. But it couldn't reflect students' comprehensive ability, innovation ability and autonomous learning ability.

The existing evaluation methods are badly in need of reform. The new methods should be used not only to check the knowledge and operating skills of students, but also evaluate the ability to solve practical problems and information literacy. The reformed evaluation system of learning effect of students are shown in table II.

TABLE II. Evaluation form of learning effect

\begin{tabular}{|l|c|}
\hline Items & Percentage \\
\hline Attendance and performance in Class & $10 \%$ \\
\hline $\begin{array}{l}\text { Situation and duration time in autonomous } \\
\text { learning system }\end{array}$ & $10 \%$ \\
\hline The completion status of comprehensive project & $40 \%$ \\
\hline Online testing & $40 \%$ \\
\hline
\end{tabular}

Comprehensive experiments and computer-based exams are the main evaluation basis for learning effect of students. Teachers arrange comprehensive project based on teaching contents and progress. Students complete the project and submit the project results and report in groups or even individually. Teachers should keep track of students' progress and make suggestions to assure the expected implementation effect. The integrated evaluation of students' knowledge, innovation ability, teamwork and communication are discussed at the end of the project.

\section{III . Conclusions}

The content of public computer course has become an important component of university students' knowledge structure. The ability of using computer is a necessary skill for contemporary university students. It is important to cultivate students' autonomous learning ability and information literacy. Based on this purpose, the curriculum reform in public computer course in universities is put forward and has achieved a good result when applied in Jianghan University. In the process of the reform, the new system needed to be deeply studied and investigated on teaching environment, teaching methods, teachers cultivation and teaching material. The reform is flawed with certain shortcomings, it remains to be further explored and improved.

\section{Reference:}

[1] Sun zheping, The thinking about the reform of talents cultivation in Application-oriented universities, China Higher Education Research,2011.4:55-57

[2] SUN Hui-jie, WANG Jian-hua, The Theory of Multiple Intelligences and Its Inspirations to Our Computer Education Reform, Computer Education, 2010.10

[3] Chen gang, Yan bin, Liu junbo, Reform of Basic Computer Education in Jianghan University, Computer Education, 2010.13(7):95-98

[4] Zhu sifeng, Zhang yuhua, The Practicing and Exploring of Computer Curriculum Revolution in Normal College, Computer Education, 2010.3:46-48

[5] Zhang yanling, Jiang xuefeng, Du chenglie, Liu junrui, The application of Parallel interactive teaching mode in course of Program Design, Computer Education, 2013.1:73-76

[6] Diamond R M, Designing and Assessing Courses and Curricula: A Practical Guide. San Francisco:Jossey-Bass Publishers, 1998.

[7] $\mathrm{Gu}$ xiaoqing, Reflect upon evaluating network-based learning systems, Global Chinese Conference on Computers in Education (GCCCE), 2002 